Article

\title{
Pharmacokinetic Properties of Arsenic Species after Intravenous and Intragastrical Administration of Arsenic Trioxide Solution in Cynomolgus Macaques Using HPLC-ICP-MS
}

\author{
Qiaoli Shi ${ }^{1}$, Mingyan Ju ${ }^{2}$, Xiaoxia Zhu ${ }^{1}$, Hui Gan ${ }^{1}$, Ruolan Gu ${ }^{1}$, Zhuona Wu ${ }^{1}$, \\ Zhiyun Meng ${ }^{1, *}$ and Guifang Dou ${ }^{1, *}$ \\ 1 Department of Pharmaceutical Sciences, Beijing Institute of Radiation Medicine, 27 Taiping Road, Haidian \\ District, Beijing 100850, China; qiaoli0212@126.com (Q.S.); 13681022512@163.com (X.Z.); \\ ganh2003@163.com (H.G.); gurl311@126.com (R.G.); nirvasen@sina.com (Z.W.) \\ 2 Shanghai Yao Jian Medical Biotechnology Limited Company. National University of science and technology, \\ University of Shanghai for Science and Technology, 128 Xiangyin Road, Yangpu District, \\ Shanghai 200433, China; 18601113236@126.com \\ * Correspondence: mengzhiyun@vip.163.com (Z.M.); dougf@bmi.ac.cn (G.D.); \\ Tel.: +86-10-66931993 (Z.M.); +86-10-66932951 (G.D.)
}

Received: 21 December 2018; Accepted: 9 January 2019; Published: 10 January 2019

\begin{abstract}
A rapid and sensitive method was established for arsenic (As) speciation based on high performance liquid chromatography coupled to inductively coupled plasma mass spectrometry (HPLC-ICP-MS). This method was validated for the quantification of four arsenic species, including arsenite $\left(\mathrm{As}^{\mathrm{III}}\right)$, arsenate $\left(\mathrm{As}^{\mathrm{V}}\right)$, monomethylarsonic acid $\left(\mathrm{MMA}^{\mathrm{V}}\right)$ and dimethylarsinic acid $\left(\mathrm{DMA}^{\mathrm{V}}\right)$ in cynomolgus macaque plasma. Separation was achieved in just $3.7 \mathrm{~min}$ with an alkyl reverse phase column and highly aqueous mobile phase containing $20 \mathrm{mM}$ citric acid and $5 \mathrm{mM}$ sodium hexanesulfonate $(\mathrm{pH}=4.3)$. The calibration curves were linear over the range of $5-500 \mathrm{ng} \cdot \mathrm{mL}^{-1}$ (measured as As), with $r>0.99$. The above method was validated for selectivity, precision, accuracy, matrix effect, recovery, carryover effect and stability, and applied in a comparative pharmacokinetic study of arsenic species in cynomolgus macaque samples following intravenous and intragastrical administration of arsenic trioxide solution $\left(0.80 \mathrm{mg} \cdot \mathrm{kg}^{-1} ; 0.61 \mathrm{mg} \cdot \mathrm{kg}^{-1}\right.$ of arsenic); in addition, the absolute oral bioavailability of the active ingredient $\mathrm{As}^{\mathrm{III}}$ of arsenic trioxide in cynomolgus macaque samples was derived as $60.9 \pm 16.1 \%$.
\end{abstract}

Keywords: arsenic trioxide; HPLC-ICP-MS; arsenic species; cynomolgus macaque; plasma; pharmacokinetic; bioavailability

\section{Introduction}

Despite the well-known toxicity of arsenic (As), arsenic trioxide (ATO) has been used for centuries. In the 18th century, Doctor Thomas Fowler developed a solution of arsenic trioxide in potassium bicarbonate $(1 \% w / v)$ for the treatment of a variety of infectious and malignant diseases, including asthma, epilepsy, eczema and psoriasis [1,2]. In the 1970s, Chinese scholars found that ATO has a significant positive effect on acute promyelocytic leukemia (APL), with much less adverse side effects compared with conventional chemotherapeutic drugs [3,4]. Meanwhile, ATO was approved by the Food and Drug Administration (FDA) for use as a first-line anticancer drug for the treatment of relapsed or refractory APL in 2000 [5]. It was found that the rate of complete remission in relapsed patients could be as high as $92 \%$ with ATO alone [6]. Preclinical studies have shown that arsenic has 
multiple mechanisms of action, including apoptosis and leukemia cell differentiation [7-10]. Thus, it has a broad prospect of clinical application.

The typical ATO regimen is 4-8 weeks of intravenous infusion; however, there are many obstacles to intravenous administration, particularly over such a long term. Potential problems include inconvenience, risk from the injection, cardiac toxicity, cost of long-term injection and hospitalization management, which jointly make the treatment extremely challenging. Oral formulation of ATO may solve these issues and is easier to manage; the potential toxicity of arsenic can be relieved by using an appropriate dosage, while adverse effects on the heart can be greatly reduced [11-14]. However, oral administration is currently not widely used. The University of Hong Kong has successfully developed an oral formulation of ATO. A clinical study showed that oral ATO is highly effective in relapsed APL, with efficacy comparable to that of intravenous ATO [15]. However, there is no comprehensive report on the pharmacokinetics of arsenic species after treatment with oral ATO.

Arsenic (As) can be converted into different chemical forms or species upon entering the body, including inorganic arsenic [arsenite $\left(\mathrm{As}^{\mathrm{III}}\right)$, arsenate $\left(\mathrm{As}^{\mathrm{V}}\right)$ ] and organic forms [monomethylarsonic acid $\left(\mathrm{MMA}^{\mathrm{V}}\right)$, dimethylarsinic acid $\left(\mathrm{DMA}^{\mathrm{V}}\right)$, arsenobetaine (AsB), arsenocholine (AsC) and so on]. It is widely acknowledged that the toxicological and biochemical properties of trace elements depend to a large extent on species. Inorganic arsenic is more toxic than the organic counterpart, while AsB, $\mathrm{AsC}$ and other arsenosugars are considered to be non-toxic [16]. Arsenite has a direct affinity to the sulfhydryl group, inducing structural modifications in proteins and enzyme inactivation $[17,18]$. Arsenate is similar to phosphate in biochemical properties, and can impair ATP synthesis [19]. $\mathrm{MMA}^{\mathrm{V}}$ is an intermediate metabolite of arsenic metabolism, with certain toxicity [20]. DMA ${ }^{\mathrm{V}}$ is the predominant methylated metabolite, which is considered a tumor promoter [21-23]. Therefore, there are high concerns about $\mathrm{As}^{\mathrm{III}}, \mathrm{As}^{\mathrm{V}}, \mathrm{MMA}^{\mathrm{V}}$ and $\mathrm{DMA}^{\mathrm{V}}$ (Figure 1) in clinical studies.

High performance liquid chromatography (HPLC) coupled to inductively coupled plasma mass spectrometry (ICP-MS) is a widely used technique in elemental speciation of compounds such as arsenic, chromium, mercury, selenium and antimony [24-28]. Arsenic species in human urine have been analyzed; although urine is a commonly accepted indicator of arsenic exposure [29-31], arsenic in blood may indicate exposure to recent arsenic-containing drugs. In addition, arsenic mostly binds to blood cells [32], and exists in free state in plasma for distribution to various body tissues; therefore, it is necessary to detect arsenic species in plasma. However, the pharmacokinetic data of arsenic species in plasma are presently limited [33].

Oral and intravenous administration of ATO are two different drug delivery routes that may generate different types and concentrations of arsenic species in the body, resulting in toxicity differences. In this study, we developed and validated an HPLC-ICP-MS method to simultaneously quantitate the concentrations of $\mathrm{As}^{\mathrm{III}}, \mathrm{As}^{\mathrm{V}}, \mathrm{MMA}^{\mathrm{V}}$ and $\mathrm{DMA}^{\mathrm{V}}$ in cynomolgus macaque plasma samples within $3.7 \mathrm{~min}$. This method was successfully used to assess the pharmacokinetic properties of As ${ }^{\mathrm{III}}$, $\mathrm{As}^{\mathrm{V}}, \mathrm{MMA}^{\mathrm{V}}$ and $\mathrm{DMA}^{\mathrm{V}}$ in cynomolgus macaque plasma following intravenous and intragastrical administration of arsenic trioxide solution $\left(0.80 \mathrm{mg} \cdot \mathrm{kg}^{-1} ; 0.61 \mathrm{mg} \cdot \mathrm{kg}^{-1}\right.$ of arsenic). The absolute bioavailability of the active ingredient As ${ }^{\mathrm{III}}$ of ATO was determined. The present findings provide novel insights into the development of oral ATO formulation and a reliable scientific basis for clinical precision medicine.

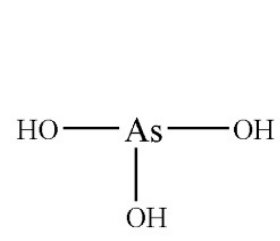

Arsenite

$\left(\mathrm{As}^{\mathrm{II}}\right)$

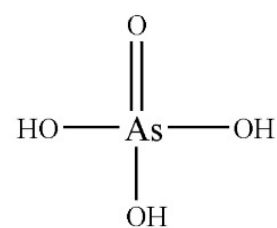

Arsenate

$\left(\mathrm{As}^{\mathrm{v}}\right)$

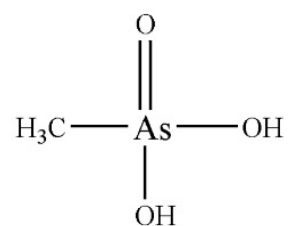

Monomethylarsonic acid

(MMA $\left.{ }^{v}\right)$

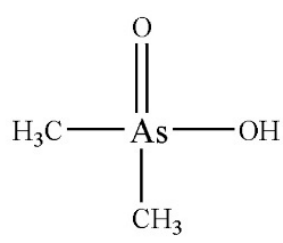

Dimethylarsinic acid

$\left(\mathrm{DMA}^{\mathrm{v}}\right.$ )

Figure 1. Chemical structures of the four arsenic species. 


\section{Results and Discussion}

\subsection{Method Development}

The method was assessed for compliance with the bioanalytical method validation of the European Medicines Agency (EMA) [34] and referred to the Chinese Food and Drug Administration (CFDA) [35].

\subsubsection{Optimization of the HPLC-ICP-MS Method}

In this study, we selected a reverse phase column to separate the four As species. The method used alkyl sulfonate and arsenide of anionic form to develop ion-pair compounds, which showed hydrophobicity and could be retained and separated by the reverse phase column. In HPLC-ICP-MS, the mobile phase of HPLC should not only be suitable for separation but also compatible with the ICP-MS system. Isocratic elution was used with a mobile phase composed of aqueous solutions of $20 \mathrm{mM}$ citric acid and $5 \mathrm{mM}$ sodium hexanesulfonate, adjusted to $\mathrm{pH} 4.3$ with $2 \mathrm{M}$ sodium hydroxide. This mobile phase achieved satisfactory separation of the four As species within $3.7 \mathrm{~min}$. In practical applications, the mobile phase and plasma samples containing high amounts of total dissolved solids (TDS) introduced into the ICP-MS system could cause the matrix to accumulate on the sampling cone, resulting in instrument signal drift and gradual loss of sensitivity in long-term analysis. To correct this, post column online internal standard (IS, Rhodium $-{ }^{103} \mathrm{Rh}, 1.0 \mu \mathrm{g} \cdot \mathrm{mL}^{-1}$ ) addition was performed via a T-type three-way valve (two inlets and one outlet). This valve allows on-line mixing of the sample eluate and internal standard solutions. With post-column addition of the ISTD, the signal of the internal standard appeared at a relatively constant level, rather than a chromatographic peak. As a multi-element detector, ICP-MS can determine Rh ISTD and As analyte signals almost simultaneously; thus, point-to-point internal standard correction was used to eliminate any drift in arsenic signals. Figure 2 shows the stable IS $\left({ }^{103} \mathrm{Rh}\right)$ signal during the analysis, which demonstrates the good stability of this method.

For detecting arsenic in plasma samples, ${ }^{75} \mathrm{As}^{+}$may show spectral overlap with ${ }^{40} \mathrm{Ar}^{35} \mathrm{Cl}^{+}$and ${ }^{40} \mathrm{Ca}^{35} \mathrm{Cl}^{+}$polyatomic ions, which would yield false results for As amounts. In this work, the helium collision cell mode was employed to effectively remove such plasma-based and matrix-based polyatomic interferences, allowing an accurate determination of As signals in the complex plasma sample matrix.

\subsubsection{Sample Preparation}

In this study, we found $\mathrm{As}{ }^{\mathrm{III}}$ transformation into $\mathrm{As}^{\mathrm{V}}$, which may be due to As ${ }^{\mathrm{III}}$ instability in the aerobic environment. To prevent species inter-conversion during the process of sample collection and treatment, addition of $0.05 \mathrm{~g}$ solid ammonium sulfate per $100 \mu \mathrm{L}$ of plasma was found to have a clear and obvious inhibitory effect on $\mathrm{As}{ }^{\mathrm{III}}$ conversion to $\mathrm{As}^{\mathrm{V}}$. We divided the experiment into two groups, including the $\mathrm{As}^{\mathrm{III}}$ and $\mathrm{As}^{\mathrm{V}}$ groups (five parallel samples per group). In the As ${ }^{\mathrm{III}}$ group, $10 \mu \mathrm{L}$ standard solution of $A s^{I I I}$ with or without ammonium sulfate $(0.05 \mathrm{~g})$ was mixed with $100 \mu \mathrm{L}$ of blank cynomolgus macaque plasma (As ${ }^{\mathrm{III}}$ at a final concentration of $400 \mathrm{ng} / \mathrm{mL}$ ). In the $\mathrm{As}^{\mathrm{V}}$ group, the same procedure was followed except that $\mathrm{As}^{\mathrm{III}}$ was substituted by $\mathrm{As}^{\mathrm{V}}$. All samples were processed by the method described in "3.4 Sample preparation". In the As ${ }^{\mathrm{III}}$ group, $\mathrm{As}^{\mathrm{V}}$ was detected with or without ammonium sulfate, and comprised $0.6 \pm 0.04 \%$ and $11.1 \pm 0.69 \%$ of the sum of inorganic arsenic $\left(\mathrm{As}^{\mathrm{III}}\right.$ and $\left.\mathrm{As}^{\mathrm{V}}\right)$, respectively. This indicated that plasma supplemented with ammonium sulfate could clearly inhibit the formation of $\mathrm{As}^{\mathrm{V}}$. In the $\mathrm{As}^{\mathrm{V}}$ group, the other three arsenic species (As ${ }^{\mathrm{III}}, \mathrm{MMA}^{\mathrm{V}}$ and $\mathrm{DMA}^{\mathrm{V}}$ ) were not detected with or without ammonium sulfate, suggesting that ammonium sulfate addition or not would not change $\mathrm{As}^{\mathrm{V}}$ during sample processing. According to the above results, we hypothesized that ammonium sulfate inactivates certain enzymes in cynomolgus macaque plasma, thereby inhibiting the conversion of $\mathrm{As}^{\mathrm{III}}$ to $\mathrm{As}^{\mathrm{V}}$.

A methanol and acetonitrile $(7: 3, v / v)$ mixture was used for protein precipitation. Addition of organic solvents has also been found to improve ionization, and therefore, increase signals for poorly-ionized elements such as arsenic. However, high levels of organic solvent in samples can lead 
to carbon (soot) deposition on the sampling cone. This would affect signal stability and intensity, as well as the life expectancy of the cone. When the organic solvent content exceeds a certain level, operating conditions must be changed to avoid soot deposition and the possibility of plasma signals being extinguished. For example, a narrower torch injector, lower spray chamber temperature and addition of a small oxygen flow to the carrier gas can all allow $100 \%$ volatile solvent solutions to be run. However, in this work, we avoided the problems associated with organic solvents by drying the samples under nitrogen at $60{ }^{\circ} \mathrm{C}$ for solvent evaporation. The residue was then re-dissolved and concentrated in the mobile phase ready for sample analysis.

\subsection{Analytical Method Validation}

\subsubsection{Selectivity}

The selectivity of the method for each As species was assessed with blank plasma samples from six individual test subjects. No interfering peaks were observed with the same retention times (RTs) as $\mathrm{As}^{\mathrm{III}}, \mathrm{MMA}^{\mathrm{V}}$ and $\mathrm{DMA}^{\mathrm{V}}$, respectively. However, a peak had the same RT as $\mathrm{As}^{\mathrm{V}}$. The total arsenic content of feed and drinking water provided to experimental animals was in line with Chinese national standards [36,37]. However, a peak presumed to be $\mathrm{As}^{\mathrm{V}}$ was detected in the six blank cynomolgus macaque plasma samples, accounting for $33.3 \pm 4.2 \%$ of the lower limit of quantitation (LLOQ, $5 \mathrm{ng} \cdot \mathrm{mL}^{-1}$ ). Therefore, we hypothesized that $\mathrm{As}^{\mathrm{V}}$ occurs as an endogenous component in cynomolgus macaques. In experiments assessing cynomolgus macaques, we also observed a small exogenous contribution to total $\mathrm{As}^{\mathrm{V}}$. This was most likely derived from the fruits and vegetables used for diet supplementation every day, because the daily diet was the main source of inorganic arsenic exposure prior to the administration of ATO. The total arsenic of fruits and vegetables has been reported to include a large proportion of inorganic arsenic [38]. Meanwhile, $\mathrm{As}^{\mathrm{V}}$ is more stable than $\mathrm{As}{ }^{\mathrm{III}}$ in an aerobic environment, thus, inorganic As (iAs) in the environment is mostly in the form of $\mathrm{As}^{\mathrm{V}}$ [39-41].

The typical chromatograms obtained from blank samples, spiked plasma samples with analytes at the LLOQ, and plasma samples after dosing of arsenic trioxide solution are presented in Figure 2A-C. The retention times of $\mathrm{As}^{\mathrm{III}}, \mathrm{As}^{\mathrm{V}}, \mathrm{MMA}^{\mathrm{V}}$ and $\mathrm{DMA}^{\mathrm{V}}$ were $2.77 \mathrm{~min}, 2.30 \mathrm{~min}, 2.51 \mathrm{~min}$ and $3.32 \mathrm{~min}$, respectively.
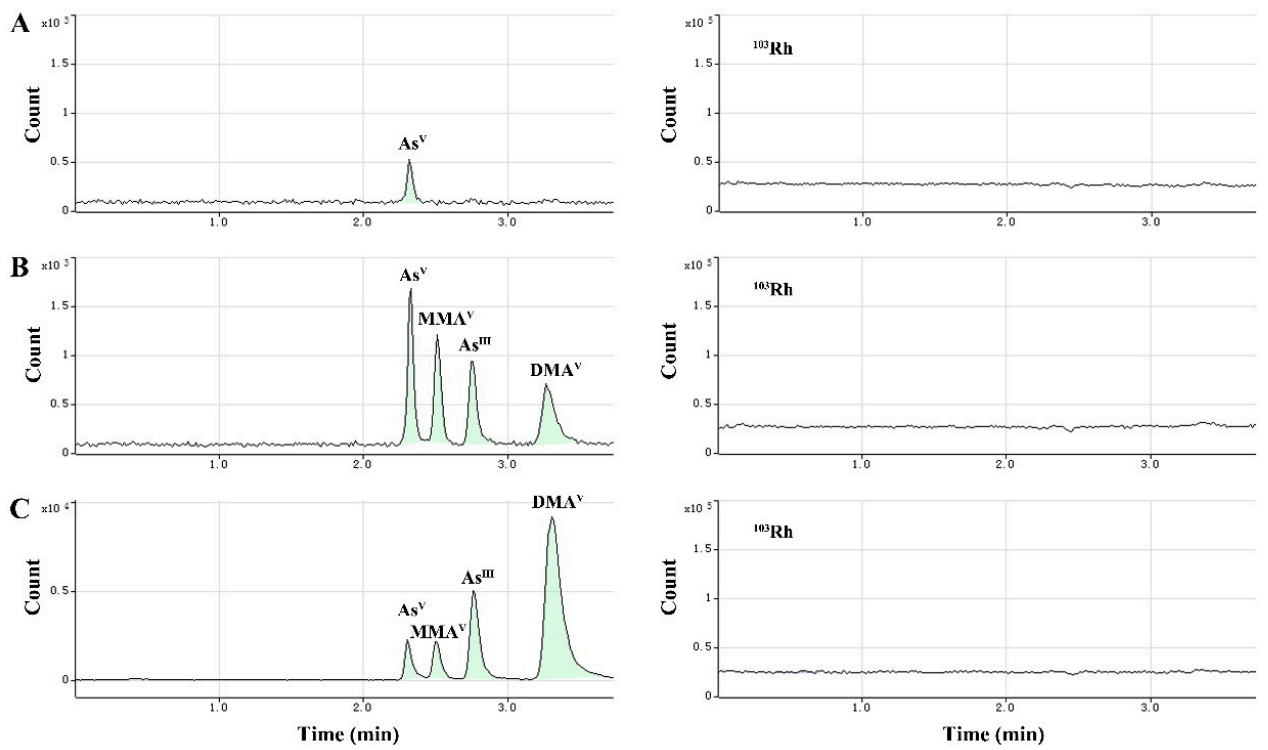

Figure 2. Typical chromatograms showing baseline separation of As species, including $\mathrm{As}^{\mathrm{V}}$ (retention time $(\mathrm{RT})=2.30 \mathrm{~min}), \mathrm{MMA}^{\mathrm{V}}(\mathrm{RT}=2.51 \mathrm{~min}), \mathrm{As}^{\mathrm{III}}(\mathrm{RT}=2.77 \mathrm{~min})$ and $\mathrm{DMA}^{\mathrm{V}}(\mathrm{RT}=3.32 \mathrm{~min})$, and $\mathrm{Rh}$ internal standard (right-side chromatograms). (A) Blank plasma sample, (B) blank plasma sample spiked with the analytes at the lower limit of quantitation (LLOQ), (C) cynomolgus macaque plasma sample after dosing of arsenic trioxide solution. 


\subsubsection{Linearity and Sensitivity}

The calibration standards of $\mathrm{As}^{\mathrm{III}}, \mathrm{As}^{\mathrm{V}}, \mathrm{MMA}^{\mathrm{V}}$ and $\mathrm{DMA}^{\mathrm{V}}$ ranged from 5-500 $\mathrm{ng} \cdot \mathrm{mL}^{-1}$ (count as As). The typical calibration equations were: $\mathrm{As}^{\mathrm{III}}, \mathrm{y}=425.4 \mathrm{x}+264.7(r=0.9998) ; \mathrm{As}^{\mathrm{V}}$, $\mathrm{y}=428.2 \mathrm{x}+917.0(r=0.9999) ; \mathrm{MMA}^{\mathrm{V}}, \mathrm{y}=470.8 \mathrm{x}+178.7(r=0.9999) ; \mathrm{DMA}^{\mathrm{V}}, \mathrm{y}=487.9 \mathrm{x}+384.1$ $(r=0.9999)$. The LLOQ of all four analytes was $5 \mathrm{ng} \cdot \mathrm{mL}^{-1}$ (count as As). The results showed a good linearity over the concentration range of interest.

\subsubsection{Accuracy and Precision}

The intra- and inter-day accuracy and precision were determined by LLOQs and quality control (QC) samples at low, medium and high concentrations. The accuracy and precision data are summarized in Table 1. The intra- and inter-day precision (relative standard deviation, RSD $\%$ ) of the four arsenic species was less than $12.7 \%$; accuracy (relative error, RE\%) ranged from $-6.8 \%$ to $4.7 \%$, demonstrating that the method had good accuracy and reproducibility.

\subsubsection{Matrix effects and Recovery}

Matrix effect and recovery data are presented in Table 2. The matrix effects of $\mathrm{As}^{\mathrm{III}}$, $\mathrm{As}^{\mathrm{V}}$, $\mathrm{MMA}^{\mathrm{V}}$ and $\mathrm{DMA}^{\mathrm{V}}$ were in the ranges of 99.7-101.9\%, 93.5-98.4\%, 95.9-97.0\% and 98.6-101.3\%, respectively. RSD (\%) values for the four analytes at two QC concentrations were $\leq 3.2 \%$. These findings demonstrated that there was no obvious ion suppression or enhancement from the plasma matrix in this approach.

The overall recoveries of $\mathrm{As}^{\mathrm{III}}, \mathrm{As}^{\mathrm{V}}, \mathrm{MMA}^{\mathrm{V}}$ and $\mathrm{DMA}^{\mathrm{V}}$ were in the ranges of 36.5-38.7\%, $33.7-37.3 \%$, 39.5-39.8\% and 39.5-41.8\%, respectively. RSD (\%) values for the four analytes were $\leq 3.8 \%$. The results met the criteria that RSD (\%) should not exceed $15 \%$. It has been reported that the total arsenic content in blood cells is much higher than that in plasma [32,42], suggesting that arsenicals bind more to blood cells after entering the body, and the major arsenic in blood cells is likely bound to hemoglobin $[43,44]$. Additionally, arsenicals have the ability to bind to plasma proteins in animals $[45,46]$, thus, the low recovery rate in this experiment may be caused by the combination of arsenic species and plasma proteins.

\subsubsection{Carryover Effects}

Carryover effects for As ${ }^{\mathrm{III}}, \mathrm{MMA}^{\mathrm{V}}$ and $\mathrm{DMA}^{\mathrm{V}}$ were less than $20 \%$ of the LLOQ, thus, they met the method requirements. However, $\mathrm{As}^{\mathrm{V}}$ was measured at $34.1 \pm 5.3 \%$ of the LLOQ, exceeding the acceptable standard. In "2.2.1 Specificity", we mentioned that $\mathrm{As}$ V was an endogenous component in cynomolgus macaque plasma, accounting for $33.3 \pm 4.2 \%$ of the LLOQ, which is very close to its carryover value. Thus, the measured "carryover" can be explained by the endogenous As in blank plasma samples. Moreover, $\mathrm{As}^{\mathrm{V}}$ is an inactive component among metabolites of arsenic trioxide. $\mathrm{RSD} \%$ and $\mathrm{RE} \%$ of accuracy and precision for $\mathrm{As}^{\mathrm{V}}$ were less than $15 \%$ (Section 2.2.3), which met the requirements of the EMA and CFDA, demonstrating that $\mathrm{As}^{\mathrm{V}}$ quantitation was reliable. 
Table 1. Detection precision and accuracy for the four analytes in cynomolgus macaque plasma $(n=6)$.

\begin{tabular}{|c|c|c|c|c|c|c|c|c|}
\hline \multirow{2}{*}{$\begin{array}{l}\text { Arsenic } \\
\text { Species }\end{array}$} & \multirow{2}{*}{$\begin{array}{l}\text { Spiked Concentration } \\
\left(\mathbf{n g} \cdot \mathrm{mL}^{-1}\right)\end{array}$} & \multicolumn{3}{|c|}{ Measured Concentration $\left(\mathrm{ng} \cdot \mathrm{mL}^{-1}\right)($ Mean $\pm \mathrm{SD}, n=6)$} & \multirow{2}{*}{$\begin{array}{l}\text { Overall Mean } \\
\left(\mathrm{ng} \cdot \mathrm{mL}^{-1}\right)\end{array}$} & \multirow{2}{*}{$\begin{array}{c}\text { Intra-DayRSD } \\
(\%)\end{array}$} & \multirow{2}{*}{$\begin{array}{c}\text { Inter-DayRSD } \\
(\%)\end{array}$} & \multirow{2}{*}{ RE $(\%$} \\
\hline & & Batch 1 & Batch 2 & Batch 3 & & & & \\
\hline \multirow[t]{4}{*}{$\mathrm{As}^{\mathrm{III}}$} & 5.0 & $4.8 \pm 0.1$ & $4.8 \pm 0.3$ & $5.2 \pm 0.3$ & 5.0 & 5.4 & 12.7 & -1.8 \\
\hline & 8.1 & $7.8 \pm 0.3$ & $7.8 \pm 0.6$ & $8.3 \pm 0.2$ & 8.0 & 5.2 & 9.6 & -1.2 \\
\hline & 80.7 & $83.4 \pm 2.4$ & $77.6 \pm 1.7$ & $84.0 \pm 1.7$ & 81.6 & 2.4 & 10.6 & 1.2 \\
\hline & 403.5 & $421.3 \pm 16.0$ & $406.8 \pm 18.7$ & $410.3 \pm 10.2$ & 412.8 & 3.7 & 4.5 & 2.3 \\
\hline \multirow[t]{4}{*}{$\mathrm{As}^{\mathrm{V}}$} & 5.0 & $5.2 \pm 0.2$ & $4.8 \pm 0.2$ & $5.2 \pm 0.3$ & 5.1 & 4.5 & 9.5 & 0.5 \\
\hline & 8.1 & $8.7 \pm 0.5$ & $8.3 \pm 0.4$ & $8.2 \pm 0.6$ & 8.4 & 5.8 & 7.3 & 4.1 \\
\hline & 80.7 & $87.7 \pm 3.2$ & $84.7 \pm 2.6$ & $79.6 \pm 1.7$ & 84.0 & 3.1 & 11.8 & 4.2 \\
\hline & 403.3 & $435.5 \pm 7.7$ & $430.0 \pm 11.8$ & $401.1 \pm 9.4$ & 422.2 & 2.3 & 10.7 & 4.7 \\
\hline \multirow[t]{4}{*}{$\mathrm{MMA}^{\mathrm{V}}$} & 5.0 & $5.0 \pm 0.2$ & $5.0 \pm 0.2$ & $4.9 \pm 0.4$ & 4.9 & 5.9 & 4.2 & -1.2 \\
\hline & 8.0 & $8.3 \pm 0.4$ & $8.4 \pm 0.3$ & $8.4 \pm 0.4$ & 8.4 & 4.5 & 0.4 & 4.4 \\
\hline & 80.2 & $83.4 \pm 1.3$ & $84.9 \pm 2.6$ & $82.0 \pm 2.9$ & 83.4 & 2.8 & 4.2 & 4.1 \\
\hline & 400.8 & $414.7 \pm 8.0$ & $416.6 \pm 5.6$ & $396.5 \pm 17.3$ & 409.3 & 2.8 & 6.6 & 2.1 \\
\hline \multirow[t]{4}{*}{$\mathrm{DMA}^{\mathrm{V}}$} & 5.0 & $4.6 \pm 0.3$ & $4.8 \pm 0.5$ & $4.6 \pm 0.5$ & 4.7 & 9.3 & 7.1 & -6.8 \\
\hline & 8.0 & $7.9 \pm 0.7$ & $8.2 \pm 0.4$ & $8.2 \pm 0.5$ & 8.1 & 7.1 & 4.1 & 0.9 \\
\hline & 80.3 & $83.3 \pm 2.4$ & $82.5 \pm 1.6$ & $80.6 \pm 1.0$ & 82.1 & 2.1 & 4.0 & 2.3 \\
\hline & 401.5 & $418.2 \pm 4.6$ & $417.0 \pm 11.1$ & $398.7 \pm 5.1$ & 411.3 & 1.8 & 6.5 & 2.4 \\
\hline
\end{tabular}


Table 2. Matrix effects and recovery rates for the four analytes in cynomolgus macaque plasma.

\begin{tabular}{|c|c|c|c|c|c|}
\hline \multirow{2}{*}{$\begin{array}{l}\text { Arsenic } \\
\text { Species }\end{array}$} & \multirow{2}{*}{$\begin{array}{c}\text { Concentration } \\
\left(\mathrm{ng} \cdot \mathrm{mL}^{-1}\right)\end{array}$} & \multicolumn{2}{|c|}{ Matrix Effect $(n=6)$} & \multicolumn{2}{|c|}{ Recovery $(n=6)$} \\
\hline & & Mean \pm SD (\%) & RSD (\%) & Mean \pm SD (\%) & RSD (\%) \\
\hline \multirow{2}{*}{$\mathrm{As}^{\mathrm{III}}$} & 8 & $101.9 \pm 3.3$ & 3.2 & $38.7 \pm 0.8$ & 2.1 \\
\hline & 400 & $99.7 \pm 0.6$ & 0.6 & $36.5 \pm 1.1$ & 3.0 \\
\hline \multirow{2}{*}{$\mathrm{As}^{\mathrm{V}}$} & 8 & $98.4 \pm 2.0$ & 2.0 & $37.3 \pm 1.3$ & 3.6 \\
\hline & 400 & $93.5 \pm 1.8$ & 1.9 & $33.7 \pm 0.9$ & 2.7 \\
\hline \multirow{2}{*}{$\mathrm{MMA}^{\mathrm{V}}$} & 8 & $97.0 \pm 2.5$ & 2.6 & $39.5 \pm 1.5$ & 3.8 \\
\hline & 400 & $95.9 \pm 1.6$ & 1.7 & $39.8 \pm 0.9$ & 2.3 \\
\hline \multirow{2}{*}{$\mathrm{DMA}^{\mathrm{V}}$} & 8 & $101.3 \pm 2.7$ & 2.7 & $41.8 \pm 1.2$ & 3.0 \\
\hline & 400 & $98.6 \pm 1.3$ & 1.3 & $39.5 \pm 0.7$ & 1.9 \\
\hline
\end{tabular}

\subsubsection{Stability}

Stability data are displayed in Table 3. The results showed that the four species of arsenic in blank plasma were stable at room temperature for $8 \mathrm{~h}$, after three freeze and thaw cycles, and at $-80^{\circ} \mathrm{C}$ for 172 days. The processed samples were stable at $4{ }^{\circ} \mathrm{C}$ for $24 \mathrm{~h}$, and after loading onto the auto-sampler for $24 \mathrm{~h}$. Furthermore, the stock solution of arsenic species was stable at $4{ }^{\circ} \mathrm{C}$ for 50 days.

\subsection{Pharmacokinetic Profiles of Arsenic Species in Mammals}

This method was successfully applied to the pharmacokinetic study of the four arsenic species in mammalian plasma after intravenous (i.v.) and intragastrical (i.g.) administration of arsenic trioxide solution at a single dose of $0.80 \mathrm{mg} / \mathrm{kg}$ (equivalent to $0.61 \mathrm{mg} \mathrm{As} / \mathrm{kg}$ ), respectively.

The plasma concentration-time profiles of the four species after intravenous and intragastrical administration of arsenic trioxide solution are shown in Figure 3, and mean pharmacokinetic parameters are summarized in Table 4. As shown in Figure 3, $\mathrm{As}^{\mathrm{III}}$ is an effective anti-cancer compound and could be detected within $8 \mathrm{~h}$ of both intravenous and intragastrical administration. $\mathrm{As}^{\mathrm{V}}$ was detected within $4 \mathrm{~h} . \mathrm{MMA}^{\mathrm{V}}$ as an intermediate metabolite appeared at $4-8 \mathrm{~h}$, and remained at a stable and relatively low level in both groups. As the predominant metabolite, $\mathrm{DMA}^{\mathrm{V}}$ was found at high levels, starting from $2 \mathrm{~h}$ after dosing through $24 \mathrm{~h}$ in both groups.
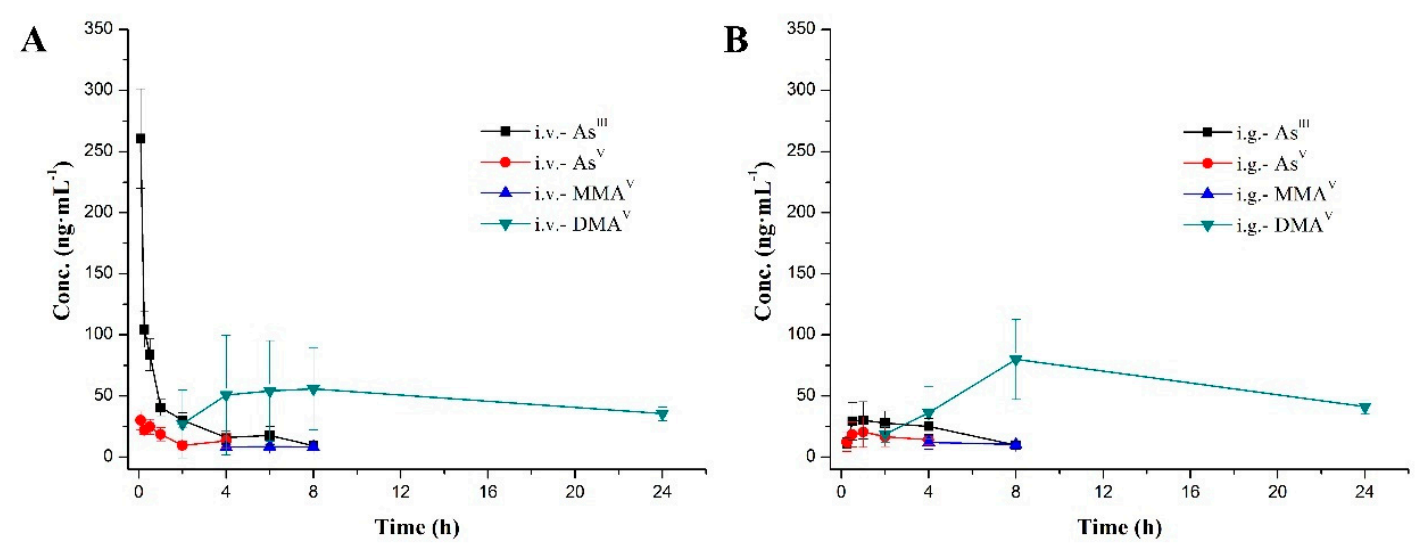

Figure 3. Mean plasma concentration-time curves of the four arsenic species after administration (A. intravenous; B. intragastrical) at a single dose of $0.80 \mathrm{mg} \cdot \mathrm{kg}^{-1}\left(0.61 \mathrm{mg} \cdot \mathrm{kg}^{-1}\right.$ of arsenic). Data are mean $\pm \mathrm{SD}(n=10)$. 
Table 3. Stability data of the four arsenicals in cynomolgus macaque plasma under different storage conditions $(n=6)$.

\begin{tabular}{|c|c|c|c|c|c|c|c|c|c|c|c|c|c|}
\hline \multirow[b]{2}{*}{ Storage Conditions } & \multirow{2}{*}{$\begin{array}{c}\text { Concentration } \\
\left(\mathrm{ng} \cdot \mathrm{mL}^{-1}\right)\end{array}$} & \multicolumn{3}{|c|}{$\mathrm{As}^{\mathrm{III}}$} & \multicolumn{3}{|c|}{$\mathrm{As}^{\mathrm{V}}$} & \multicolumn{3}{|c|}{ MMA $^{\mathrm{V}}$} & \multicolumn{3}{|c|}{ DMA $^{\mathrm{V}}$} \\
\hline & & $\begin{array}{c}\text { Mean } \pm \text { SD } \\
\left(\mathrm{ng} \cdot \mathrm{mL}^{-1}\right)\end{array}$ & $\begin{array}{c}\text { RSD } \\
(\%)\end{array}$ & $\begin{array}{l}\mathrm{RE} \\
(\%)\end{array}$ & $\begin{array}{c}\text { Mean } \pm \text { SD } \\
\left(\mathrm{ng} \cdot \mathrm{mL}^{-1}\right)\end{array}$ & $\begin{array}{l}\text { RSD } \\
(\%)\end{array}$ & $\begin{array}{l}\mathrm{RE} \\
(\%)\end{array}$ & $\begin{array}{l}\text { Mean } \pm \text { SD } \\
\left(\mathrm{ng} \cdot \mathrm{mL}^{-1}\right)\end{array}$ & $\begin{array}{l}\text { RSD } \\
(\%)\end{array}$ & $\begin{array}{l}\text { RE } \\
(\%)\end{array}$ & $\begin{array}{c}\text { Mean } \pm \text { SD } \\
\left(\mathrm{ng} \cdot \mathrm{mL}^{-1}\right)\end{array}$ & $\begin{array}{l}\text { RSD } \\
(\%)\end{array}$ & $\begin{array}{l}\mathrm{RE} \\
(\%)\end{array}$ \\
\hline \multirow[t]{2}{*}{ Room temperature for $8 \mathrm{~h}$} & 8 & $8.4 \pm 0.5$ & 6.1 & 4.2 & $8.2 \pm 0.5$ & 5.8 & 1.4 & $8.0 \pm 0.2$ & 2.8 & -0.7 & $8.2 \pm 0.7$ & 8.0 & 1.6 \\
\hline & 400 & $405.9 \pm 8.6$ & 2.1 & 0.6 & $404.2 \pm 13.6$ & 3.4 & 0.2 & $394.8 \pm 9.5$ & 2.4 & -1.5 & $394.2 \pm 10.0$ & 2.5 & -1.8 \\
\hline \multirow[t]{2}{*}{ Three freeze-thaw cycles } & 8 & $7.8 \pm 0.2$ & 2.5 & -3.7 & $7.4 \pm 0.3$ & 3.5 & -7.7 & $7.5 \pm 0.2$ & 2.4 & -6.1 & $7.5 \pm 0.1$ & 1.6 & -6.5 \\
\hline & 400 & $393.2 \pm 8.6$ & 2.2 & -2.6 & $401.9 \pm 11.6$ & 2.9 & -0.4 & $390.5 \pm 8.3$ & 2.1 & -2.6 & $393.4 \pm 8.1$ & 2.1 & -2.0 \\
\hline \multirow[t]{2}{*}{ Long term for 172 days $\left(-80^{\circ} \mathrm{C}\right)$} & 8 & $7.8 \pm 0.4$ & 4.5 & -3.5 & $7.7 \pm 0.3$ & 3.9 & -4.9 & $7.9 \pm 0.2$ & 2.5 & -1.5 & $7.6 \pm 0.3$ & 4.4 & -5.3 \\
\hline & 400 & $402.4 \pm 11.7$ & 2.9 & -0.7 & $407.1 \pm 5.5$ & 1.3 & 2.1 & $388.3 \pm 9.2$ & 2.4 & -3.7 & $397.6 \pm 7.6$ & 1.9 & -1.0 \\
\hline \multirow[t]{2}{*}{ Processed sample for $24 \mathrm{~h}\left(4^{\circ} \mathrm{C}\right)$} & 8 & $8.5 \pm 0.6$ & 7.5 & 4.9 & $8.3 \pm 0.3$ & 3.1 & 2.6 & $8.3 \pm 0.1$ & 1.2 & 3.6 & $8.1 \pm 0.2$ & 2.7 & 0.6 \\
\hline & 400 & $404.1 \pm 11.9$ & 3.0 & 0.2 & $401.5 \pm 13.4$ & 3.3 & -0.4 & $386.3 \pm 6.1$ & 1.6 & -3.6 & $388.9 \pm 13.6$ & 3.5 & -3.2 \\
\hline \multirow[t]{2}{*}{ Autosampler for $24 \mathrm{~h}$} & 8 & $7.6 \pm 0.3$ & 3.6 & -5.2 & $7.3 \pm 0.3$ & 3.7 & -10.1 & $7.1 \pm 0.3$ & 4.7 & -11.0 & $7.5 \pm 0.3$ & 4.5 & -6.7 \\
\hline & 400 & $398.4 \pm 6.5$ & 1.6 & -1.3 & $398.5 \pm 17.3$ & 4.3 & -1.2 & $388.8 \pm 10.0$ & 2.6 & -3.0 & $394.4 \pm 8.9$ & 2.2 & -1.8 \\
\hline \multirow[t]{2}{*}{ Stock solution for 50 days $\left(4^{\circ} \mathrm{C}\right)$} & 8 & $8.0 \pm 0.1$ & 1.7 & -4.2 & $8.0 \pm 0.4$ & 5.1 & -2.3 & $7.7 \pm 0.3$ & 3.4 & -3.4 & $8.2 \pm 0.5$ & 5.5 & 1.5 \\
\hline & 400 & $402.1 \pm 9.5$ & 2.4 & -3.5 & $406.3 \pm 7.0$ & 1.7 & -0.3 & $405.3 \pm 7.9$ & 1.9 & 1.2 & $406.5 \pm 6.2$ & 1.5 & 1.0 \\
\hline
\end{tabular}

Table 4. Pharmacokinetic parameters of the four arsenic species $(n=10)$.

\begin{tabular}{|c|c|c|c|c|c|c|c|c|}
\hline \multirow{3}{*}{ Parameter (unit) } & \multicolumn{8}{|c|}{ Mean $\pm \mathrm{SD}\left(0.80 \mathrm{mg} \cdot \mathrm{kg}^{-1}, 0.61 \mathrm{mg} \cdot \mathrm{kg}^{-1}\right.$ of Arsenic $)$} \\
\hline & \multicolumn{2}{|c|}{$\mathrm{As}^{\mathrm{III}}$} & \multicolumn{2}{|c|}{$\mathrm{As}^{\mathrm{V}}$} & \multicolumn{2}{|c|}{ MMA $^{\mathbf{V}}$} & \multicolumn{2}{|c|}{ DMA $^{\mathrm{V}}$} \\
\hline & i.g. & i.v. & i.g. & i.v. & i.g. & i.v. & i.g. & i.v. \\
\hline $\mathrm{T}_{\max }(\mathrm{h})$ & $1.7 \pm 1.3$ & $0.083 \pm 0.0$ & $3.6 \pm 7.3$ & $0.17 \pm 0.18$ & $8.8 \pm 5.6$ & $5.6 \pm 2.1$ & $11.2 \pm 6.7$ & $13.4 \pm 9.2$ \\
\hline $\mathrm{C}_{\max }\left(\mathrm{ng} \cdot \mathrm{mL}^{-1}\right)$ & $40.8 \pm 8.4$ & $260.7 \pm 40.7$ & $24.5 \pm 10.9$ & $30.5 \pm 7.7$ & $13.8 \pm 6.1$ & $9.9 \pm 1.7$ & $80.7 \pm 31.8$ & $65.1 \pm 41.4$ \\
\hline $\mathrm{AUC}_{\text {last }}\left(\mathrm{h} \cdot \mathrm{ng} \cdot \mathrm{mL}^{-1}\right)$ & $148.1 \pm 39.0$ & $243.1 \pm 51.8$ & $172.6 \pm 139.9$ & $55.9 \pm 23.7$ & $92.6 \pm 98.2$ & $57.6 \pm 9.7$ & $1225.0 \pm 364.4$ & $1012 \pm 511$ \\
\hline $\operatorname{AUC}_{\text {INF_obs }}\left(\mathrm{h} \cdot \mathrm{ng} \cdot \mathrm{mL}^{-1}\right)$ & / & $286.5 \pm 76.8$ & / & $76.6 \pm 34.0$ & / & / & / & / \\
\hline $\mathrm{CL}_{\text {_obs }}\left(\mathrm{L} \cdot \mathrm{h}^{-1} \cdot \mathrm{kg}^{-1}\right)$ & / & $2.3 \pm 0.5$ & / & $9.9 \pm 5.2$ & / & / & / & / \\
\hline $\mathrm{V}_{\text {ss }}$ obs $\left(\mathrm{L} \cdot \mathrm{kg}^{-1}\right)$ & / & $7.4 \pm 0.5$ & / & $21.2 \pm 4.5$ & / & / & / & / \\
\hline $\begin{array}{c}\mathrm{MRT}_{\text {last }}(\mathrm{h}) \\
\mathrm{F}(\%)\end{array}$ & $\begin{array}{c}3.1 \pm 0.9 \\
60.9 \pm 16.1\end{array}$ & $2.1 \pm 0.5$ & $6.1 \pm 5.5$ & $1.4 \pm 0.5$ & $6.6 \pm 3.3$ & $3.8 \pm 0.9$ & $13.1 \pm 1.0$ & $13.2 \pm 1.8$ \\
\hline
\end{tabular}

/: The pharmacokinetic parameters cannot be calculated. 
As ${ }^{\mathrm{III}}$ reached maximum plasma concentrations $\left(\mathrm{C}_{\max }\right)$ of $260.7 \pm 40.7$ and $40.8 \pm 8.4 \mathrm{ng} \cdot \mathrm{mL}^{-1}$, $\mathrm{AUC}_{\text {last }}$ values of $243.1 \pm 51.8$ and $148.1 \pm 39.0 \mathrm{~h} \cdot \mathrm{ng} \cdot \mathrm{mL}^{-1}$, following intravenous and intragastric administration of arsenic trioxide solution at a single dose of $0.80 \mathrm{mg} / \mathrm{kg}$ (equivalent to $0.61 \mathrm{mg} \mathrm{As} / \mathrm{kg}$ ), respectively. The time of maximum concentration $\left(T_{\max }\right)$ after intravenous administration was the first time point $(0.083 \mathrm{~h})$, and the intragastrical administration was $1.7 \pm 1.3 \mathrm{~h}$. As ${ }^{\mathrm{V}}$, reached maximum plasma concentrations $\left(C_{\max }\right)$ of $30.5 \pm 7.7 \mathrm{ng} \cdot \mathrm{mL}^{-1}$ (i.v.) and $24.5 \pm 10.9 \mathrm{ng} \cdot \mathrm{mL}^{-1}$ (i.g.), with $\mathrm{AUC}_{\text {last }}$ values of $55.9 \pm 23.7 \mathrm{~h} \cdot \mathrm{ng} \cdot \mathrm{mL}^{-1}$ (i.v.) and $172.6 \pm 139.9 \mathrm{~h} \cdot \mathrm{ng} \cdot \mathrm{mL}^{-1}$ (i.g.), respectively. As for $\mathrm{MMA}^{\mathrm{V}}$, $\mathrm{AUC}_{\text {last }}$ values of the i.v. and i.g. group were both lower compared with those of the other three species. The pharmacokinetics (PK) parameters of $\mathrm{DMA}^{\mathrm{V}}$ after i.v. were similar to i.g. counterparts; the mean residence time ( $\left.\mathrm{MRT}_{\text {last }}\right)$ was the longest among the four arsenic species.

In addition, absolute oral bioavailability of $\mathrm{As}^{\mathrm{III}}$, which was estimated by dividing $\mathrm{AUC}_{\text {i.g. }}$ by $\mathrm{AUC}_{\text {i.v. }}$, was $60.9 \pm 16.1 \%$, indicating that orally administered drug could be well absorbed. Arsenic trioxide existed in the solution as As ${ }^{\text {III }}$, which is the pharmacologically active species of arsenic trioxide, while $\mathrm{As}^{\mathrm{V}}, \mathrm{MMA}^{\mathrm{V}}$ and $\mathrm{DMA}^{\mathrm{V}}$ are all metabolites of $\mathrm{As}^{\mathrm{III}}$. Therefore, ATO bioavailability assessment using $\mathrm{As}^{\mathrm{III}}$ levels is more accurate than employing total arsenic content.

From the above, the durations of the parent drug $\left(\mathrm{As}^{\mathrm{III}}\right)$ and its three metabolites $\left(\mathrm{As}^{\mathrm{V}}, \mathrm{MMA}^{\mathrm{V}}\right.$ and $\mathrm{DMA}^{\mathrm{V}}$ ) in vivo after intragastrical administration were relatively consistent with intravenous administration. The most striking difference was that the instantaneous plasma concentration of the parent drug ( $\left.\mathrm{As} \mathrm{s}^{\mathrm{III}}\right)$ after intravenous administration was very high $\left(\mathrm{C}_{\max }, 260.7 \pm 40.7 \mathrm{ng} \cdot \mathrm{mL}^{-1}\right.$, i.v.), while that after intragastrical administration was relatively low, but was very stable in the body $\left(\mathrm{C}_{\max }, 40.8 \pm 8.4 \mathrm{ng} \cdot \mathrm{mL}^{-1}\right.$, i.g.). High instantaneous concentration results in cardiac QTc interval prolongation [14]; oral administration of $\mathrm{As}^{\mathrm{III}}$ may relieve this side effect. Therefore, oral formulations have similar therapeutic effects compared with intravenous products, but oral administration is more convenient and safer.

Generally speaking, biotransformation of inorganic arsenic involves reduction and methylation reactions in mammals. After ingestion, $\mathrm{As}^{\mathrm{V}}$ is first reduced to $\mathrm{As}{ }^{\mathrm{III}}$, which is methylated to $\mathrm{MMA}^{\mathrm{V}}$; in turn, $\mathrm{MMA}^{\mathrm{V}}$ is reduced to MMA ${ }^{\mathrm{III}}$, which is methylated to $\mathrm{DMA}^{\mathrm{V}}$, which is finally reduced to $\mathrm{DMA}^{\mathrm{III}}[41,47,48]$. Arsenic metabolism usually begins with $\mathrm{As}^{\mathrm{V}}$, which is more stable than As ${ }^{\mathrm{III}}$; indeed, $\mathrm{As}^{\mathrm{V}}$ is widely found in aerobic ecological environment [39-41]. In Figure 3, $\mathrm{As} \mathrm{s}^{\mathrm{III}}$ and $\mathrm{As} \mathrm{v}^{\mathrm{V}}$ were detected at the first time point after i.v. and i.g. administration (i.v., $0.083 \mathrm{~h}$; i.g., $0.25 \mathrm{~h}$ ). We hypothesized that a small amount of As ${ }^{\mathrm{III}}$ is rapidly transformed into $\mathrm{As}^{\mathrm{V}}$ after ATO administration in the blood or gastrointestinal tract, that is to say, in certain conditions, the first step in the metabolism of inorganic arsenic is a reversible reaction. However, the metabolic enzyme promoting such reaction remains unknown, which deserves further exploration.

The results also showed elevated standard deviation (SD) values for the four arsenic species. This suggested that there was a marked inter-individual variation in arsenic metabolism; moreover, there is a considerable species variation in arsenic methylation. The main reason for differences in inorganic arsenic methylation between species and individuals is gene polymorphism [40,49-51], which plays an important role in the regulation of enzymes involved in iAs biotransformation. Furthermore, the intestinal flora is worth assessing in relation to arsenic metabolism [52-54]. We performed statistical analysis of male-female differences in the seven pharmacokinetic parameters $\left(\mathrm{T}_{\max }, \mathrm{C}_{\max }, \mathrm{AUC}_{\text {last }}, \mathrm{AUC}_{\mathrm{INF}_{\mathrm{N}} \mathrm{obs}}, \mathrm{CL}_{\text {_obs, }} \mathrm{Vss}_{\text {_obs }}\right.$ and $\left.\mathrm{MRT}_{\text {last }}\right)$ for the four arsenic species by two-tailed t-test (IBM SPSS). There were no significant differences between males and females $(p>0.05)$ for the seven pharmacokinetic parameters in the same arsenic species and dose group, except that the pharmacological parameters $\mathrm{C}_{\max }$ and $\mathrm{AUC}_{\text {last }}(p<0.05)$ of the main metabolite $\mathrm{DMA}^{\mathrm{V}}$ after intragastrical administration were significantly different. Moreover, males had significantly higher levels than females ( $C_{\max }, 1.7$ times; $A U C_{\text {last }}, 1.5$ times). In the intravenous group, although there were no statistical differences between males and females in $\mathrm{C}_{\max }$ and $\mathrm{AUC}_{\text {last }}$ of $\mathrm{DMA}^{\mathrm{V}}(p>0.05)$, the average value of males in these two parameters were slightly higher than that of females $\left(C_{\max }\right.$, 1.4 times; $\mathrm{AUC}_{\text {last }}, 1.3$ times). It has been reported that there was a difference in gender in the amount 
of $\mathrm{DMA}^{\mathrm{V}}[55,56]$; some authors reported no differences [57]. In this study, the $\mathrm{C}_{\max }$ and $\mathrm{AUC}_{\text {last }}$ of $\mathrm{DMA}^{\mathrm{V}}$ after intravenous and intragastrical administration of ATO were slightly higher in males than that of females. We believe that slight gender differences may have an effect on arsenic methylation metabolism. The specific reasons deserve further study.

Beagle dogs were first chosen for the study, but because of strong stimulation by ATO of the gastrointestinal tract, which is especially sensitive in beagle dogs [58], vomiting was so severe that the dosage was not accurate; therefore, we needed another animal model. Some nonhuman primates, including the marmoset, chimpanzee and tamarin monkey [59-62], could not methylate inorganic arsenic, and the process of inorganic arsenic methylation acts as a detoxification mechanism [40,60]. No literature has been reported on inorganic arsenic metabolism in the cynomolgus macaque. In this study, methylated metabolites $\left(\mathrm{MMA}^{\mathrm{V}}\right.$ and $\left.\mathrm{DMA}^{\mathrm{V}}\right)$ were detected in the plasma of cynomolgus macaques after intravenous and intragastrical administration of ATO, indicating that cynomolgus macaques have methylation ability as humans [63-65]. This study provides insights into arsenic metabolism in non-human primates, and implies that the cynomolgus macaque is an ideal animal model for assessing inorganic arsenic metabolism, which has considerable guiding significance for oral administration of ATO in humans in the future.

In preliminary experiments in the cynomolgus macaque, we quantified five arsenic species in plasma $\left(\mathrm{As}^{\mathrm{III}}, \mathrm{As}^{\mathrm{V}}, \mathrm{MMA}^{\mathrm{V}}, \mathrm{DMA}^{\mathrm{V}}\right.$ and AsB) by HPLC-ICP-MS. The results showed that AsB amounts at any time point in plasma were lower than the LLOQ $\left(5 \mathrm{ng} \cdot \mathrm{mL}^{-1}\right)$, and the AsB peak was at the end of the chromatogram $\left(\mathrm{As}^{\mathrm{V}}, \mathrm{RT}=2.24 \mathrm{~min} ; \mathrm{MMA}^{\mathrm{V}}, \mathrm{RT}=2.48 \mathrm{~min} ; \mathrm{As}{ }^{\mathrm{III}}, \mathrm{RT}=2.74 \mathrm{~min} ; \mathrm{DMA}^{\mathrm{V}}\right.$, $\mathrm{RT}=3.24 \mathrm{~min} ; \mathrm{AsB}, \mathrm{RT}=3.83 \mathrm{~min}$ ); $\mathrm{AsB}$ is usually considered to be non-toxic. For the above reasons, AsB data were not shown in this study.

\section{Materials and Methods}

\subsection{Chemicals and Reagents}

Arsenic trioxide solution was manufactured by Jinan Chuan Cheng Pharmaceutical R\&D Co., Ltd. (Jinan, China). Arsenic acid, arsenious acid, monomethylarsonic acid and dimethylarsinic acid solutions were purchased from NIMC (National Institute of Metrology China, Beijing, China). ICP-MS Internal Standard Mixture and ICP-MS Stock Tuning Solution were purchased from Agilent Technologies Co., Ltd. (Santa Clara, CA, USA). High purity citric acid ( $\geq 99.5 \%$ ), sodium hexane-sulfonate $(\geq 98 \%)$ and sodium hydroxide $(\geq 99.99 \%)$ were purchased from Sigma Aldrich Chemicals (St. Louis, MO, USA). Methanol, acetonitrile, and isopropanol were obtained from Thermo Fisher Scientific Inc., (Waltham, MA, USA). Ammonium sulfate was from SCRC (Sinopharm Chemical Reagent Co., Ltd., Beijing, China). Concentrated nitric acid (68.8-69.8\%) was purchased from DUKSAN (KYUNGKIDO. ANSAN, Korea). Sodium chloride injection (500 mL:4.5 g) was obtained from Cisen Pharmaceutical Co., Ltd. (Jining, China). Cynomolgus macaque plasma was supplied by Xieerxin Biology Resource (Beijing, China). Deionized water with a resistivity of $18.2 \mathrm{M} \Omega \cdot \mathrm{cm}^{-1}$ was prepared with a Milli-Q ${ }^{\circledR}$ Advantage A10 (Millipore Corp., Billerica, MA, USA).

\subsection{Instruments and HPLC-ICP-MS Conditions}

An Agilent 1260 HPLC system comprising a quaternary pump, autosampler and vacuum degasser was used for As species separation, coupled to an Agilent 7700x ICP-MS (Agilent, Santa Clara, CA, USA) for detection. The column exit was simply connected to the nebulizer of the ICP-MS by PFA tubing. The reverse phase column Agilent ZORBAX SB-Aq (4.6 mm id $\times 250 \mathrm{~mm}, 5 \mu \mathrm{m})$ was maintained at room temperature throughout the analysis. The mobile phase was $20 \mathrm{mM}$ citric acid and $5 \mathrm{mM}$ sodium hexanesulfonate, adjusted to $\mathrm{pH} 4.3$ with $2 \mathrm{M}$ sodium hydroxide. The injection volume was $10 \mu \mathrm{L}$; a flow rate of $1.0 \mathrm{~mL} \cdot \mathrm{min}^{-1}$ was adopted, with a run time of $3.7 \mathrm{~min}$.

An Agilent 7700x ICP-MS with an Octopole Reaction System (ORS ${ }^{3}$, Santa Clara, CA, USA) collision/reaction cell (CRC) was used for As species detection. The 7700 ICP-MS was fitted with 
a standard Micromist nebulizer and a Scott spray chamber (temperature controlled at $2{ }^{\circ} \mathrm{C}$ ). Typical operating parameters for ICP-MS were: RF power, $1550 \mathrm{~W}$; carrier gas flow rate, $0.8 \mathrm{~L} \cdot \mathrm{min}^{-1}$; makeup gas flow rate, $0.4 \mathrm{~L} \cdot \mathrm{min}^{-1}$; sampling depth; $8.0 \mathrm{~mm}$.

Helium cell gas was used to rule out potential polyatomic ion interference $\left({ }^{40} \mathrm{Ar}^{35} \mathrm{Cl}^{+}\right.$or $\left.{ }^{40} \mathrm{Ca}^{35} \mathrm{Cl}^{+}\right)$ on ${ }^{75} \mathrm{As}^{+}$. The helium cell gas flow rate was $4.0 \mathrm{~mL} \cdot \mathrm{min}^{-1}$. ${ }^{103} \mathrm{Rh}$ was used as post-column online internal standard to correct long-term signal drift caused by the plasma matrix.

\subsection{Preparation of Stock and Working Solutions}

A mixed stock solution of $\mathrm{As}^{\mathrm{III}}, \mathrm{As}^{\mathrm{V}}, \mathrm{MMA}^{\mathrm{V}}$ and $\mathrm{DMA}^{\mathrm{V}}$ was obtained by appropriate dilution of standard solutions with purified water, to a final concentration of $5000 \mathrm{ng} \cdot \mathrm{mL}^{-1}$ (measured as As) for $\mathrm{As}^{\mathrm{III}}, \mathrm{As}^{\mathrm{V}}, \mathrm{MMA}^{\mathrm{V}}$ and $\mathrm{DMA}^{\mathrm{V}}$. The stock solution was stored at $4{ }^{\circ} \mathrm{C}$, and working standard solutions were freshly prepared before use. An internal standard working solution $\left(1.0 \mu \mathrm{g} \cdot \mathrm{mL}^{-1}\right)$ was prepared in isopropanol and $5 \%$ nitric acid $(5: 95, v / v)$ in a final volume of $100 \mathrm{~mL}$. The internal standard was also stored at $4{ }^{\circ} \mathrm{C}$.

\subsection{Sample Preparation}

Plasma samples were thawed to room temperature before use. A total of $0.05 \mathrm{~g}$ ammonium sulfate was added into each empty centrifuge tube before use to prevent $\mathrm{As}^{\mathrm{III}}$ conversion to $\mathrm{As}^{\mathrm{V}}$. Then, $100 \mu \mathrm{L}$ plasma sample was added to the tube and vortexed for $2 \mathrm{~min}$. Next, $10 \mu \mathrm{L}$ water and $200 \mu \mathrm{L}$ methanol/acetonitrile $(7: 3, v / v)$ were added for protein precipitation. The mixture was centrifuged at $12,000 \mathrm{rpm}$ for $15 \mathrm{~min}$ at $4{ }^{\circ} \mathrm{C}$ after vortex-mixing for $2 \mathrm{~min}$. The supernatant $(120 \mu \mathrm{L})$ was transferred to a $1.5 \mathrm{~mL}$ Eppendorf tube, dried under nitrogen at $60^{\circ} \mathrm{C}$, and dissolved in $100 \mu \mathrm{L}$ mobile phase after cooling to room temperature. The mixture was centrifuged at $12,000 \mathrm{rpm}$ for $3 \mathrm{~min}$ at $4{ }^{\circ} \mathrm{C}$ after vortex-mixing for $2 \mathrm{~min}$. The resulting supernatant was transferred into auto-sampler vials and analyzed by HPLC-ICP-MS with $10 \mu \mathrm{L}$ injection volume.

The calibration plasma standards were prepared by spiking blank plasma from cynomolgus macaques with the working standard solutions covering a concentration range from 5 to $500 \mathrm{ng} \cdot \mathrm{mL}^{-1}$ for $\mathrm{As}^{\mathrm{III}}, \mathrm{As}^{\mathrm{V}}, \mathrm{MMA}^{\mathrm{V}}$ and $\mathrm{DMA}^{\mathrm{V}}$. Seven calibrators were used to cover the quantitation range: 5, 10, 20, 50, 100, 250 and $500 \mathrm{ng} \cdot \mathrm{mL}^{-1}$. Quality control (QC) samples were prepared by the same procedures in plasma at concentrations of 8,80 and $400 \mathrm{ng} \cdot \mathrm{mL}^{-1}$ for $\mathrm{As}^{\mathrm{III}}, \mathrm{As}^{\mathrm{V}}, \mathrm{MMA}^{\mathrm{V}}$ and $\mathrm{DMA}^{\mathrm{V}}$.

\subsection{Method Validation}

\subsubsection{Selectivity}

Selectivity was assessed in appropriate blank matrix samples from six individual test subjects to assess for potential interference. Any peaks present in the chromatograms should contribute $<20 \%$ of LLOQ to analyte peaks.

\subsubsection{Linearity and Sensitivity}

Seven-point calibration curves were fitted using weighted least squares linear regression of peak areas after correction with the online internal standard $\left({ }^{103} \mathrm{Rh}\right)$. Each batch of calibration solutions was freshly prepared the day of use. Blank plasma samples were used to confirm the absence of interference. The LLOQ was used to determine the sensitivity of the method; the deviation should not exceed $20 \%$.

\subsubsection{Accuracy and Precision}

For accuracy and precision validation, six sample replicates at four different concentration levels (LLOQ, low, mid and high) were assessed on three different days. Intra- and inter-day precision (RSD\%) and accuracy (RE\%) were required to be within $\pm 15 \%$, except for the LLOQ which should be within $\pm 20 \%$. 


\subsubsection{Matrix effects and Recovery}

The effects of the sample matrix were evaluated by comparing peak areas in blank plasma collected from six individual test subjects. The extracted matrix was spiked with standard solutions, and peak areas were compared to those determined in pure reference standard solutions at the same concentrations. The ratio of peak areas was performed at low and high concentrations, respectively. The RSD $\%$ of area ratio at each concentration should be less than $15 \%$.

Spike recovery in macaque plasma was determined by comparing peak areas in QC samples with those of the corresponding spiked solutions added to supernatants of the processed blank plasma samples. The recovery of analytes does not need to be $100 \%$ but should be precise and reproducible. The RSD \% of the peak area ratio at each concentration should be less than $15 \%$.

\subsubsection{Carryover Effect}

The carryover effect was determined by injecting a blank plasma sample after the upper limit of quantification (ULOQ) standard. The peak areas of blank plasma samples run after ULOQ should be less than $20 \%$ of those measured in the LLOQ sample.

\subsubsection{Stability}

Stability evaluation involved sample preparation, analysis and storage. The stability test used six QC samples at low and high concentrations, respectively.

Stability of QC samples was investigated after storage at room temperature for $8 \mathrm{~h}$, after three complete freeze/thaw cycles $\left(-80{ }^{\circ} \mathrm{C}\right.$ to room temperature) or storage at $-80{ }^{\circ} \mathrm{C}$ for 172 days. The processed stability samples were evaluated after storage at $4{ }^{\circ} \mathrm{C}$ for $24 \mathrm{~h}$ and after placement on the auto-sampler for $24 \mathrm{~h}$. Stock solution stability was also evaluated after storage at $4{ }^{\circ} \mathrm{C}$ for 50 days. The relative error (RE\%) for any stability test set was required to be within $\pm 15 \%$.

\subsection{Pharmacokinetic Assessment}

Twenty cynomolgus macaques (ten males and ten females, aged 2-6 years) were obtained from Guangxi Guidong primate development experimental Co. Ltd., Wuzhou, China. Animals were fed separately and maintained under standard laboratory conditions (temperature, $18{ }^{\circ} \mathrm{C}$ to $26^{\circ} \mathrm{C}$; relative humidity, $40 \%$ to $70 \% ; 12 / 12 \mathrm{~h}$ light/darkness). The animals were supplemented with about $50 \mathrm{~g}$ of fruits or vegetables per day, unless otherwise stated. All animal experiments were conducted according to the Guide for the Care and Use of Laboratory Animals (National Research Council of the USA, 1996), and approved by the Association for Assessment and Accreditation of Laboratory Animal Care. The license for experimental animal production was SYXK (Suzhou) 2016-0024. All animal studies were approved by the Animal Ethics Committee of China Pharmaceutical University (Approval number ACU16-1086).

The twenty test animals were fasted overnight before the experiments, and randomly divided into two groups, including the intravenous $(n=10)$ and intragastrical $(n=10)$ groups, comprising half males and females. Each animal received a single dose of $0.80 \mathrm{mg} \cdot \mathrm{kg}^{-1}$ of arsenic trioxide solution $\left(0.5 \mathrm{mg} / \mathrm{mL}\right.$, equivalent to $0.61 \mathrm{mg} \cdot \mathrm{kg}^{-1}$ of arsenic), by intragastrical (i.g.) or intravenous (i.v.) administration. Blood samples of about $0.5 \mathrm{~mL}$ were drawn from the animal's forelimb or hindlimb vein into dipotassium ethylenediaminetetraacetic acid (EDTA-2K) tubes at the following time points after dosing: 0.25, 0.5, 1.0, 2.0, 4.0, 8.0, and $24 \mathrm{~h}$ (i.g.); 0.083, 0.25, 0.5, 1.0, 2.0, 4.0, 6.0, 8.0 and $24 \mathrm{~h}$ (i.v.). Plasma was collected by centrifugation at $2000 \mathrm{~g}$ for $10 \mathrm{~min}$ at $2-8{ }^{\circ} \mathrm{C}$ and stored at $-70{ }^{\circ} \mathrm{C}$ until analysis.

The animal experiments were performed by JOINN Laboratories, Inc. following Good Laboratory Practice (GLP) guidelines. 


\subsection{Data Analysis}

Microsoft Office Excel was used for data calculation. Origin 8.0 was used to draw graphs. ChemDraw Ultra 8.0 was used to generate the chemical structures of the four arsenic species. Agilent ICP-MS MassHunter Workstation version A 01.02 was used for data acquisition and analysis. WinNonlin Version 6.4 (Pharsight Corp., MO, USA) was used to determine the pharmacokinetic parameters of arsenical species based on a non-compartmental method. $\mathrm{T}_{\max }$ and $\mathrm{C}_{\max }$ were observed values, and the calculation method for AUC was linear log trapezoidal. The absolute oral bioavailability (F) of As ${ }^{\mathrm{III}}$, due to the same dose of intravenous and intragastrical administration, was estimated by dividing $A U C_{\text {i.g. }}$ by $\mathrm{AUC}_{\text {i.v. }}$ Other parameters were calculated using non-compartmental model based on the actual measured concentration values. All data were expressed in terms of the means with their standard deviation. Statistical analysis of male and female differences in each group was performed using t-test two-tailed method (IBM SPSS software). The $p$ value was set as $<0.05$ for statistical significance.

\section{Conclusion}

In this study, we developed a rapid and stable method to simultaneously determine $\mathrm{As}^{\mathrm{III}}, \mathrm{As}^{\mathrm{V}}$, $\mathrm{MMA}^{\mathrm{V}}$ and DMA ${ }^{\mathrm{V}}$ amounts in cynomolgus macaque plasma. The separation technique of HPLC has the advantage of a short run time $(3.7 \mathrm{~min})$. The established and confirmed technique was successfully applied to perform a comparative pharmacokinetic study of arsenic species after intravenous and intragastrical administration of arsenic trioxide in cynomolgus macaques. The absolute oral bioavailability of the active component $\mathrm{As}{ }^{\mathrm{III}}$ of arsenic trioxide in cynomolgus macaque plasma was found to be $60.9 \pm 16.1 \%$, for the first time. Oral formulation of arsenic trioxide is convenient and safe, and could play an important role in long-term arsenic treatment in the future.

Author Contributions: Conceptualization, Z.M. and G.D.; Methodology, Q.S., Z.M. and G.D.; Project administration, G.D.; Resources, M.J.; Software, Q.S., X.Z. and Z.W.; Supervision, Z.M.; Writing-original draft, Q.S.; Writing—review \& editing, H.G. and R.G.

Funding: This research received no external funding.

Acknowledgments: The authors gratefully thank Juane Song, Agilent Technologies (China), for cordial help regarding the methodology.

Conflicts of Interest: The authors declare no conflict of interest.

\section{Abbreviations}

ATO

arsenic trioxide

APL acute promyelocytic leukemia

HPLC-ICP-MS high performance liquid chromatography coupled to inductively coupled plasma mass spectrometry

iAs

As ${ }^{\text {III }}$

inorganic arsenic

$\mathrm{As}^{\mathrm{V}}$

arsenite

$\mathrm{MMA}^{\mathrm{V}}$

$\mathrm{DMA}^{\mathrm{V}}$

MMA $^{\text {III }}$

arsenate

DMA $^{\text {III }}$

monomethylarsonic acid

dimethylarsinic acid

methylarsonous acid

i.v.

dimethylarsinous acid

i.g.

intravenous administration

SD

intragastrical administration

$\mathrm{C}_{\max }$

standard deviation

$\mathrm{C}_{\max }$

maximum concentration

$\mathrm{AUC}_{\text {last }}$

time of maximum concentration

area under the curve from the time of dosing to the last measurable concentration 


$\begin{array}{ll}\mathrm{AUC}_{\mathrm{INF}} \mathrm{obs} & \text { AUC from dosing time extrapolated to infinity } \\ \mathrm{CL} \_ \text {obs } & \text { total clearance } \\ \mathrm{Vss}_{\mathrm{S}} \mathrm{obs} & \text { volume of distribution at steady state } \\ \mathrm{MRT}_{\text {last }} & \text { mean residence time }\end{array}$

\section{References}

1. Sarquis, M. Arsenic and Old Myths. J. Chem. Educ. 1979, 56, 815-818. [CrossRef]

2. Kwong, Y.L.; Todd, D. Delicious poison: Arsenic trioxide for the treatment of leukemia [letter]. Blood 1997, 89, 3487-3488. [PubMed]

3. Shen, Z.X.; Ni, J.H.; Li, X.S.; Xiong, S.M.; Qiu, Q.Y.; Zhu, J.; Tang, W.; Sun, G.L.; Yang, K.Q.; Chen, Y.; et al. Use of Arsenic Trioxide $\left(\mathrm{As}_{2} \mathrm{O}_{3}\right)$ in the Treatment of Acute Promyelocytic Leukemia (APL): II. Clinical Efficacy and Pharmacokinetics in Relapsed Patients. Blood 1997, 89, 3354-3360. [PubMed]

4. Wang, Z.Y.; Chen, Z. Acute promyelocytic leukemia: From highly fatal to highly curable. Blood 2008, 111, 2505-2515. [CrossRef] [PubMed]

5. U.S. Food and Drug Administration, Trisenox. Available online: https://www.accessdata.fda.gov/ drugsatfda_docs/label/2000/21248lbl.pdf (accessed on 25 September 2010).

6. Soignet, S.L.; Maslak, P.; Wang, Z.G.; Jhanwar, S.; Calleja, E.; Dardashti, L.J.; Corso, D.; Deblasio, A.; Gabrilove, J.; Scheinberg, D.A.; et al. Complete remission after treatment of acute promyelocytic leukemia with arsenic trioxide. N. Engl. J. Med. 1998, 339, 1341-1348. [CrossRef] [PubMed]

7. Chen, G.Q.; Zhu, J.; Shi, X.G.; Ni, J.H.; Zhong, H.J.; Si, G.Y.; Jin, X.L.; Tang, W.; Li, X.S.; Xong, S.M.; et al. In vitro studies on cellular and molecular mechanisms of arsenic trioxide $\left(\mathrm{As}_{2} \mathrm{O}_{3}\right)$ in the treatment of acute promyelocytic leukemia: $\mathrm{As}_{2} \mathrm{O}_{3}$ induces NB4 cell apoptosis with downregulation of $\mathrm{Bcl}-2$ expression and modulation of PML-RAR alpha/PML proteins. Blood 1996, 88, 1052-1061.

8. Shao, W.; Fanelli, M.; Ferrara, F.F.; Riccioni, R.; Rosenauer, A.; Davison, K.; Lamph, W.W.; Waxman, S.; Pelicci, P.G.; Lo Coco, F.; et al. Arsenic trioxide as an inducer of apoptosis and loss of PML/RAR alpha protein in acute promyelocytic leukemia cells. J. Natl. Cancer Inst. 1998, 90, 124-133. [CrossRef]

9. Chen, G.Q.; Shi, X.G.; Tang, W.; Xiong, S.M.; Zhu, J.; Cai, X.; Han, Z.G.; Ni, J.H.; Shi, G.Y.; Jia, P.M.; et al. Use of arsenic trioxide $\left(\mathrm{As}_{2} \mathrm{O}_{3}\right)$ in the treatment of acute promyelocytic leukemia (APL): $\mathrm{I} . \mathrm{As}_{2} \mathrm{O}_{3}$ exerts dose-dependent dual effects on APL cells. Blood 1997, 89, 3345-3353.

10. Jing, Y.K.; Dai, J.; Chalmers-Redman, R.M.E.; Tatton, W.G.; Waxman, S. Arsenic trioxide selectively induces acute promyelocytic leukemia cell apoptosis via a hydrogen peroxide-dependent pathway. Blood 1999, 94, 2102-2111.

11. Torka, P.; Ustwani, O.A.; Wetzler, M.; Wang, E.S.; Griffiths, E.A. Swallowing a bitter pill-oral arsenic trioxide for acute promyelocytic leukemia. Blood Rev. 2016, 30, 201-211. [CrossRef]

12. Firkin, F. Oral administration of arsenic trioxide in the treatment of acute promyelocytic leukaemia and accelerated phase chronic myeloid leukaemia: An Australian single-centre study. Intern. Med. J. 2012, 42, 948-952. [CrossRef] [PubMed]

13. Au, W.Y.; Kwong, Y.L. Arsenic trioxide: Safety issues and their management. Acta Pharmacol. Sin. 2008, 29, 296-304. [CrossRef]

14. Siu, C.W.; Au, W.Y.; Yung, C.; Kumana, C.R.; Lau, C.P.; Kwong, Y.L.; Tse, H.F. Effects of oral arsenic trioxide therapy on QT intervals in patients with acute promyelocytic leukemia: Implications for long-term cardiac safety. Blood 2006, 108, 103-106. [CrossRef] [PubMed]

15. Au, W.Y.; Kumana, C.R.; Kou, M.; Mak, R.; Chan, G.C.F.; Lam, C.W.; Kwong, Y.L. Oral arsenic trioxide in the treatment of relapsed acute promyelocytic leukemia. Blood 2003, 102, 407-408. [CrossRef] [PubMed]

16. Liu, L.H.; He, B.; Yun, Z.J.; Sun, J.; Jiang, G.B. Speciation analysis of arsenic compounds by capillary electrophoresis on-line coupled with inductively coupled plasma mass spectrometry using a novel interface. J. Chromatogr. A 2013, 1304, 227-233. [CrossRef] [PubMed]

17. Wang, Y.C.; Chaung, R.H.; Tung, L.C. Comparison of the cytotoxicity induced by different exposure to sodium arsenite in two fish cell lines. Aquat. Toxicol. 2004, 69, 67-79. [CrossRef] [PubMed]

18. Akter, K.F.; Owens, G.; Davey, D.E.; Naidu, R. Arsenic speciation and toxicity in biological systems. Rev. Environ. Contam. Toxicol. 2005, 184, 97-149. [CrossRef] [PubMed] 
19. Fattorini, D.; Regoli, F. Arsenic speciation in tissues of the Mediterranean polychaete Sabella spallanzanii. Environ. Toxicol. Chem. 2004, 23, 1881-1887. [CrossRef]

20. Moore, M.M.; Harrington-Brock, K.; Doerr, C.L. Relative genotoxic potency of arsenic and its methylated metabolites. Mutat. Res. 1997, 386, 279-290. [CrossRef]

21. Yamanaka, K.; Ohtsubo, K.; Hasegawa, A.; Hayashi, H.; Ohji, H.; Kanisawa, M.; Okada, S. Exposure to dimethylarsinic acid, a main metabolite of inorganic arsenics, strongly promotes tumorigenesis initiated by 4-nitroquinoline 1-oxide in the lungs of mice. Carcinogenesis 1996, 17, 767-770. [CrossRef]

22. Yamamoto, S.; Wanibuchi, H.; Hori, T.; Yano, Y.; Matsui-Yuasa, I.; Otani, S.; Chen, H.; Yoshida, K.; Kuroda, K.; Endo, G.; et al. Possible carcinogenic potential of dimethylarsinic acid as assessed in rat in vivo models: A review. Mutat. Res. 1997, 386, 353-361. [CrossRef]

23. Elia, A.C.; Magara, G.; Caruso, C.; Masoero, L.; Prearo, M.; Arsieni, P.; Caldaroni, B.; Dörr, A.J.M.; Scoparo, M.; Salvati, S.; et al. A comparative study on subacute toxicity of arsenic trioxide and dimethylarsinic acid on antioxidant status in Crandell Rees feline kidney (CRFK), human hepatocellular carcinoma (PLC/PRF/5), and epithelioma papulosum cyprini (EPC) cell lines. J. Toxicol. Environ. Health A 2018, 81, 333-348. [CrossRef]

24. Araujo-Barbosa, U.; Pena-Vazquez, E.; Barciela-Alonso, M.C.; Costa Ferreira, S.L.; Pinto Dos Santos, A.M.; Bermejo-Barrera, P. Simultaneous determination and speciation analysis of arsenic and chromium in iron supplements used for iron-deficiency anemia treatment by HPLC-ICP-MS. Talanta 2017, 170, 523-529. [CrossRef] [PubMed]

25. Silva, E.G.D.; Mataveli, L.R.; Arruda, M.A. Speciation analysis of selenium in plankton, Brazil nut and human urine samples by HPLC-ICP-MS. Talanta 2013, 110, 53-57. [CrossRef] [PubMed]

26. Zhu, S.; Chen, B.; He, M.; Huang, T.; Hu, B. Speciation of mercury in water and fish samples by HPLC-ICP-MS after magnetic solid phase extraction. Talanta 2017, 171, 213-219. [CrossRef] [PubMed]

27. Séby, F.; Gleyzes, C.; Grosso, O.; Plau, B.; Donard, F.X. Speciation of antimony in injectable drugs used for leishmaniasis treatment (Glucantime ${ }^{\circledR}$ ) by HPLC-ICP-MS and DPP. Anal. Bioanal. Chem. 2012, 404, $2939-2948$. [CrossRef] [PubMed]

28. Delafiori, J.; Ring, G.; Furey, A. Clinical applications of HPLC-ICP-MS element speciation: A review. Talanta 2016, 153, 306-331. [CrossRef] [PubMed]

29. Heitkernper, D.; Creed, J.; Caruso, J. Speciation of arsenic in urine using high-performance liquid chromatography with inductively coupled plasma mass spectrometric detection. J. Anal. At. Spectrom. 1989, 4, 279-284. [CrossRef]

30. Morton, J.; Mason, H. Speciation of arsenic compounds in urine from occupationally unexposed and exposed persons in the U.K. using a routine LC-ICP-MS method. J. Anal. Toxicol. 2006, 30, 293-301. [CrossRef]

31. Heitland, P.; Koster, H.D. Comparison of different medical cases in urinary arsenic speciation by fast HPLC-ICP-MS. Int. J. Hyg. Environ. Health 2009, 212, 432-438. [CrossRef]

32. Kumana, C.R.; Au, W.Y.; Lee, N.S.; Kou, M.; Mak, R.W.; Lam, C.W.; Kwong, Y.L. Systemic availability of arsenic from oral arsenic-trioxide used to treat patients with hematological malignancies. Eur. J. Clin. Pharmacol. 2002, 58, 521-526. [CrossRef] [PubMed]

33. Ebdon, L.; Fisher, A.; Roberts, N.B.; Yaqoob, M. Determination of organoarsenic species in blood plasma by HPLC-ICP MS. Appl. Organometal. Chem. 1999, 13, 183-187. [CrossRef]

34. Guideline on bioanalytical method validation. In European Medicines Agency; Committee for Medicinal Products for Human Use. Available online: http:/ / www.ema.europa.eu/docs/en_GB/document_library / Scientific_guideline/2011/08/WC500109686.pdf (accessed on 1 February 2012).

35. Pharmacopoeia Commission of, P.R.C. Guidance for Industry: Bioanalytical Method validation. In Pharmacopoeia of People's Republic of China; Part 4; National Pharmacopoeia Committee: Beijing, China, 2015; pp. 363-368.

36. General Administration of Quality Supervision, Inspection and Quarantine of the P.R. China. GB 14924.2-2001. In Laboratory Animals - Hygienic Standard for Formula Feeds, the National Standard of the P.R. China; China Standard Press: Beijing, China, 2002. (In Chinese)

37. The Ministry of Health of the P.R. China; Standardization Administration of the P.R. China. GB 5749-2006. In Standard for Drinking Water Quality, the National Standard of the P.R. China; China Standard Press: Beijing, China, 2007. (In Chinese) 
38. Cubadda, F.; Jackson, B.P.; Cottingham, K.L.; Horne, Y.O.V.; Kurzius-Spencer, M. Human exposure to dietary inorganic arsenic and other arsenic species: State of knowledge, gaps and uncertainties. Sci. Total Environ. 2016. [CrossRef] [PubMed]

39. Tamaki, S.; Frankenberger, W.T., Jr. Environmental biochemistry of arsenic. Rev. Environ. Contam. Toxicol. 1992, 124, 79-110. [PubMed]

40. Vahter, M. Mechanisms of arsenic biotransformation. Toxicology 2002, 181-182, 211-217. [CrossRef]

41. Suzuki, K.T.; Mandal, B.K.; Ogra, Y. Speciation of arsenic in body fluids. Talanta 2002, 58, 111-119. [CrossRef]

42. Guo, M.H.; Wang, W.J.; Hai, X.; Zhou, J. HPLC-HG-AFS determination of arsenic species in acute promyelocytic leukemia (APL) plasma and blood cells. J. Pharm. Biomed. Anal. 2017, 145, 356-363. [CrossRef]

43. Chen, B.; Lu, X.; Shen, S.; Arnold, L.L.; Cohen, S.M.; Le, X.C. Arsenic speciation in the blood of arsenite-treated F344 rats. Chem. Res. Toxicol. 2013, 26, 952-962. [CrossRef]

44. Shen, S.W.; Li, X.F.; Cullen, W.R.; Weinfeld, M.; Le, X.C. Arsenic Binding to Proteins. Chem. Rev. 2013, 113, 7769-7792. [CrossRef]

45. Jiang, G.; Gong, Z.; Li, X.F.; Cullen, W.R.; Le, X.C. Interaction of trivalent arsenicals with metallothionein. Chem. Res. Toxicol. 2003, 16, 873-880. [CrossRef]

46. Naranmandura, H.; Suzuki, K.T. Identification of the major arsenic-binding protein in rat plasma as the ternary dimethylarsinous-hemoglobin-haptoglobin complex. Chem. Res. Toxicol. 2008, 21, 678-685. [CrossRef] [PubMed]

47. Shiobara, Y.; Ogra, Y.; Suzuki, K.T. Animal species difference in the uptake of dimethylarsinous acid (DMA(III)) by red blood cells. Chem. Res. Toxicol. 2001, 14, 1446-1452. [CrossRef] [PubMed]

48. Gebel, T.W. Arsenic methylation is a process of detoxification through accelerated excretion. Int. J. Hyg. Environ. Health 2002, 205, 505-508. [CrossRef] [PubMed]

49. Vahter, M.; Concha, G.; Nermell, B.; Nilsson, R.; Dulout, F.; Natarajan, A.T. A unique metabolism of inorganic arsenic in native Andean women. Eur. J. Pharmacol. 1995, 293, 455-462. [CrossRef]

50. Vahter, M. Genetic polymorphism in the biotransformation of inorganic arsenic and its role in toxicity. Toxicol. Lett. 2000, 112-113, 209-217. [CrossRef]

51. Agusa, T.; Fujihara, J.; Takeshita, H.; Iwata, H. Individual variations in inorganic arsenic metabolism associated with AS3MT genetic polymorphisms. Int. J. Mol. Sci. 2011, 12, 2351-2382. [CrossRef] [PubMed]

52. Sattar, A.; Xie, S.Y.; Hafeez, M.A.; Wang, X.; Hussain, H.I.; Iqbal, Z.; Pan, Y.H.; Iqbal, M.; Shabbir, M.A.; Yuan, Z.H. Metabolism and toxicity of arsenicals in mammals. Environ. Toxicol. Pharmacol. 2016, 48, 214-224. [CrossRef]

53. Lu, K.; Cable, P.H.; Abo, R.P.; Ru, H.; Graffam, M.E.; Schlieper, K.A.; Parry, N.M.; Levine, S.; Bodnar, W.M.; Wishnok, J.S.; et al. Gut microbiome perturbations induced by bacterial infection affect arsenic biotransformation. Chem. Res. Toxicol. 2013, 26, 1893-1903. [CrossRef]

54. Lu, K.; Mahbub, R.; Cable, P.H.; Ru, H.; Parry, N.M.; Bodnar, W.M.; Wishnok, J.S.; Styblo, M.; Swenberg, J.A.; Fox, J.G.; et al. Gut microbiome phenotypes driven by host genetics affect arsenic metabolism. Chem. Res. Toxicol. 2014, 27, 172-174. [CrossRef]

55. Shen, H.; Niu, Q.; Xu, M.; Rui, D.; Xu, S.; Feng, G.; Ding, Y.; Li, S.; Jing, M. Factors affecting arsenic methylation in arsenic-exposed humans: A systematic review and meta-analysis. Int. J. Environ. Res. Public Health 2016, 13, 205. [CrossRef]

56. Hsueh, Y.M.; Chiou, H.Y.; Huang, Y.L.; Wu, W.L.; Huang, C.C.; Yang, M.H.; Lue, L.C.; Chen, G.C.; Chen, C.J. Serum beta-carotene level, arsenic methylation capability, and incidence of skin cancer. Cancer Epidemiol. Biomark. Prev. 1997, 6, 589-596. [PubMed]

57. Chiou, H.Y.; Hsueh, Y.M.; Hsieh, L.L.; Hsu, L.I.; Hsu, Y.H.; Hsieh, F.I.; Wei, M.L.; Chen, H.C.; Yang, H.T.; Leu, L.C.; et al. Arsenic methylation capacity, body retention, and null genotypes of glutathione S-transferase $\mathrm{Ml}$ and $\mathrm{Tl}$ among current arsenic-exposed residents in Taiwan. Mutat. Res. 1997, 386, 197-207. [CrossRef]

58. Burkman, A.M. Assessment of emetic and antiemetic activity. J. Pharmacol. Methods 1982, 8, $165-171$. [CrossRef]

59. Vahter, M.; Marafante, E.; Lindgren, A.; Dencker, L. Tissue distribution and subcellular binding of arsenic in Marmoset monkeys after injection of ${ }^{74}$ As-Arsenite. Arch. Toxicol. 1982, 51, 65-77. [CrossRef]

60. Vahter, M.; Marafante, E. Reduction and binding of arsenate in marmoset monkeys. Arch. Toxicol. 1985, 57, 119-124. [CrossRef] [PubMed] 
61. Vahter, M.; Couch, R.; Nermell, B.; Nilsson, R. Lack of methylation of inorganic arsenic in the Chimpanzee. Toxicol. Appl. Pharmacol. 1995, 133, 262-268. [CrossRef] [PubMed]

62. Zakharyan, R.A.; Wildfang, E.; Andaposhian, H.V. Enzymatic methylation of arsenic compounds. Toxicol. Appl. Pharmacol. 1996, 140, 77-84. [CrossRef]

63. Buchet, J.P.; Lauwerys, R.; Roels, H. Comparison of the urinary excretion of arsenic metabolites after a single oral dose of sodium arsenite, monomethylarsonate, or dimethylarsinate in man. Int. Arch. Occup. Environ. Health 1981, 48, 71-79. [CrossRef]

64. Vahter, M.; Concha, G.; Nermell, B. Factors influencing arsenic methylation in humans. J. Trace Elem. Exp. Med. 2000, 13, 173-184. [CrossRef]

65. Braman, R.S.; Foreback, C.C. Methylated forms of arsenic in the environment. Science 1973, 182, 1247-1249. [CrossRef]

Sample Availability: The standard substances (arsenic acid, arsenious acid, monomethylarsonic acid and dimethylarsinic acid solutions) and the experimental samples are available from us, because there are still standard substances and samples left.

(C) 2019 by the authors. Licensee MDPI, Basel, Switzerland. This article is an open access article distributed under the terms and conditions of the Creative Commons Attribution (CC BY) license (http:/ / creativecommons.org/licenses/by/4.0/). 